\title{
Political Party in Islamic Republic of Iran: A Review
}

\author{
Hossein Asayesh, Adlina Ab. Halim, Jayum A. Jawan \& Seyedeh Nosrat Shojaei \\ Department of Government and Civilization Studies, Faculty of Human \\ Ecology, Universiti Putra Malaysia \\ E-mail: h.asayesh@yahoo.com
}

\begin{abstract}
The political party is a means of connecting the political process with society and it helps to improve the political system. This paper looks at the history of political parties in Iran after the Islamic Revolution, and also considers the two main official political party groups: the Right Party and the Left Party. The article describes how each party shapes its views and develops its programs, and finally examines their similarities and differences in the field of economics, politics and culture.
\end{abstract}

Keywords: Political Party, Iran, the Right Wing, the Left Wing, Islamic Republic

\section{Introduction}

The idea of party development was born and nurtured in the early stages of political sociology. Lipset and Rokkan (1967), Lapalombara and Weiner, (1966) and Duverger (1964) were among those who pioneered sociological models of party formation, and they posited the idea that parties are formed as part of a social and political maturation process which culminated in the mature, democratic party systems we know today. A core feature of any democracy is the political party which serves as a vehicle through which citizens can assemble freely to define their political and policy aspirations, and campaign for public office (National Democratic Institute for International Affairs, 2001). And so, one can reasonably say as a political institution the political party exists in those systems committed to democratic governance. The existence of at least one party occurs even in dictatorial and, indeed, totalitarian systems (Lapalombara and Wiener, 1966). Besides, if we accept the suggestion by Duverger (1964) and Michels (2001) that political parties are often little more than a small group of oligarchs, we cannot disregard their role as a connector between political systems and the community (Almond \& Powell, 1966) and as "instruments of civil society" (Biezen, 2004, p. 18).

Given the importance and influence of parties as catalyst in developing the political process and democratic growth in many countries, this article aims to look at the main parties and their formation in the Islamic Republic of Iran. Consideration will also be given to how and under what conditions parties of the left and right are formed, and what similarities and differences exist between them. A brief history will also be given.

\section{The History of Political Parties in Iran}

In order to establish and maintain a civil society the Iranian people first created political parties in 1908 (Bahar, 1942; Nozari, 2001). Following formation of these parties, there were major attempts to make this western model a key feature of mainstream Iranian society, but opposition from traditional institutions and lack of knowledge among the people about its necessity meant these efforts were largely unsuccessful. A period of stagnation for political parties soon developed, and the Second World War, occupation of Iran and the fall of Reza Shah's dictatorship (1941) ushered in a new era for the parties. From 1941 to 1953, due to central government weakness, the political parties saw extensive development; however, most of them lacked overall organization. They were still largely dependent upon their founders after whose death or resignation these political parties gradually disappeared from the political arena of the country (Naghibzadeh, 1999).

In 1953 a coup d'état against Mohammad Mosaddegh (Prime Minster) and dictatorship were the dominant events in Iran, will little if any trace of independent political parties. Even if a party existed, it was by order of the king, and this state of affairs lasted until the 1979 Islamic Revolution. After this Revolution, Iranian history can be divided into three periods: the War era (1981-1989), Reconstruction era (1989-1997), and Reform era (1997-2005). In the first period (1981-1989) all attention was diverted to the Iran-Iraq war and so civil society and political development were neglected. During the second period (1989-1997) due to the huge devastation caused by the war, the energy and attention of the country was largely diverted to reconstruction, and again as in the War era, little effort was put into democratic and political development. In the third period, however, and with the election of Mohammad Khatami as president in 1997 with his promises to start social reforms, create a civil society and boost political engagement, the way was paved for growth of political parties and political development. 
Unlike the government of Khatami, Mahmud Ahmadinejad's administration viewed political parties in a negative light, considering them as unhelpful for the improvement of economic performance and making a better society. Ahmadinejad himself was an active member of the Islamic Society of Engineers before he became President. After a brief history of the growth of political parties, we will look at them more closely. This will help us to a better understanding of the real purposes behind their formation.

\section{Political Parties in Iran after Islamic Revolution}

When Bani Sadr (Note 1) was President in 1981, political parties in the Islamic Republic of Iran were divided into Islamic and National camps. After his revocation new parties formed inside the Islamic block entitled "right and left wings". Since early 1982, this distinction found its way into the Parliament and was used mainly in the economic sense.

Disagreement arose over government control of large tracts of the economy, and the interpretation of article 44 of the Constitution regarding privatization. There was also dispute over whether the various business models, such as co-operatives and private sector firms, should be religion-based or no religion-based. The two wings of the political spectrum also argued over whether to make foreign trade state-monopolized and religion-based and clashed over the key issue of nationalization of industries. So looking back one can see how the economic crisis from 1986 to 1988, the end of the war, reconstruction plans and new economic views on privatization and how best to achieve economic growth were among the major factors contributing to the formation of right and left wings.

\section{The Right Party}

The Right Party has its roots in the Shiite tradition and the governing of religious rulers over the country plays a central role in its thinking. According to them, credibility of the whole political system, more than any other factor, is based on the decree and ideas of religious rulers. The Right Party is traditionally conservative and emphasizes traditional social relationships.

\section{The Left Party}

What distinguishes this approach from the Right Party is its emphasis on executing the constitution in order to respect people's rights and to work towards enhancing political freedom. These parties believe the guarantee of legal and political freedoms is the most important component for social and political growth; for them these values have priority over other political and social issues. The Left Party gets its support among the middle class, lower class, religious groups of the political body and among the middle class layers of bureaucracy. Here we are going to introduce the outstanding parties from both sides.

\section{The Main Parties from the Right Side}

\subsection{Islamic Republic Party (Hibz-i Jumhiiri-yi Isliimii)}

The Islamic Republic Party announced its existence in 1987, following the successful Revolution in 1979, and its aim was to counter the liberal parties and movements, emphasizing the leading role of religious rulers. Among the founders are names like Mohammad Hossein Beheshti (Note 2), Abdolkarim Mousavi Ardabili (Note 3), Akbar Hashemi Rafsanjani (Note 4), Ali Khamenei (Note 5) and Mohammad Javad Bahonar (Note 6). These five people along with Hassan Ayat, Asadollah Badamchiyan, Abdullah Jasbi, Mirhossein Mousavi (Note 7), Habibollah Askar Oladi, Sayyed Mahmoud Kashani (the son of Ayatollah Abolghasem Kashani (Note 8), Mahdi Araghi and Ali Derakhshan were members of Central Council of the Islamic Republic party.

The Islamic Republic Party was seen as an essential expression of Muslim unity, supportive of the clergy against other political allies such as the Freedom Movement of Iran, Toudeh (communist) party, left and nationalist parties of the first decade after the revolution.

An explosion in the Islamic Republic party's office about three years after its formation, killed many key party members. The Party Secretary General, Mohammad Hossein Beheshti, along with tens of other keys members were killed in that terrorist attack.

Although Mohammad Javad Bahonar continued the same policies, it was barely two months later that as the prime minister he was killed, along with the president, Mohammad Ali Rajaei, by an explosion in the prime minister's office. Since then Ali Khamenei, the present supreme leader of the country has held the position of secretary general of the Islamic Republic party.

Ayatollah Khomeini ordered the dissolution of the party in 1987. It is said the main reason for its failure was the existence of opposition ideas about economic policy. The party also suffered from internal inconsistencies at the highest level, and there was tension with powerful non-religious or secular internal opposition. Following revelations of suppression of internal opponents, growing divisions within the party became ever clearer, and one 
can conclude that members' views were not uniform and only showed unity because of a common enemy. The official paper of the party, Islamic Republic Newspaper, edited by Masih Mohajeri, continued after the dissolution of the party. Ali Khamenei was the first editor of this paper which is now known as the rationalist paper.

\subsection{Society of Combatant Clergy of Tehran [SCCT]( Jiimi 'ih-yi Rouhiiniyyat-i Mubariz-i Tihran)}

This party was formed during following the Islamic Republic victory, but its political activity was under the influence of the Islamic Republic Party. At the first Islamic Parliament in 1979, the Society of Combatant Clergy of Tehran allied with the Islamic Republic Party's leadership. They stood against other groups such as nationalists and the left and took almost all the parliamentary seats.

After the dismissal of Bani Sadr from the presidency in 1981, and especially in 1982, the parties within the system were divided into supporters of a state economy and of the market economy, a distinction which also existed within the Islamic Republic Party. The prevailing situation weakened the position of the Islamic Republic Party in the eyes of members and supporters who wanted a market economy. So these fans of the market joined the Society of Combatant Clergy of Tehran and focused their activities in this community, especially after the resolution of the Islamic Republic Party.

This situation created new tensions among the clergy who did not accept this policy as presented, which finally led to a new branch of the Society of Combatant Clergy of Tehran in early 1988, called the Association of Combatant Clerics (Akhavane Kazemi, 2009). That part of the party supportive of candidates of the Society of Combatant Clergy in the fourth parliament election was split in the fifth election and then they were later called the Executives of Construction Party (ECT).

On the other hand, before the fifth election there was some disagreement between members of the Society of Combatant Clergy over their goals and responsibilities. Some members labeled themselves as beyond-party and were reluctant for any kind of interference from non-clerical people of other groups in their own executive body, though some members supported the Society of Combatant Clergy's motion towards becoming a party. Some powerful supporters outside the Society of Combatant Clergy supported this group and obviously these fans were also eager for active participation from the mentioned group in the internal organization of the Society of Combatant Clergy. The conflict reached up as high as Mohammadreza Mahdavi Kani, the current secretary general of the Society of Combatant Clergy, who, though he was the first choice of the advocators, resigned his post (Mortajy, 2000).

The Society of Combatant Clergy of Tehran released their candidates' list before the fifth parliamentary election, and so this signaled that this clerical body was going to be a party. In the seventh presidential election, the party supported Nategh Nouri (Note 9), a rival of Khatami, but they suffered a bad defeat and ceded the presidency to the Left Party. They almost lost all the elective positions; however, they had great influence in appointing some positions such as the Judiciary Power, the Guardian Council, Iranian Revolutionary Guards and Religious organizations. Consistently, they could stop the Khatami administration's efforts to encourage political reform. These organizations made strenuous efforts to govern in Parliament during Khatami's period, and so many of the reformists were disqualified by the Guardian Council, and consequently they couldn't take many seats in the sixth parliament.

The ninth presidential elections presented this clerical institution with a dilemma, whether to support Akbar Hashemi Rafsanjani or not, and so they decided not to support any candidates officially and instead took a neutral role. Following the election they said they were ready to support the government. Founders of the Society of Combatant Clergy were also initiators and theorists of the Islamic Republic of Iran, some of whom were killed by their opponents just after the revolution. Among them were Morteza Motahari, Seyed Mohammad Hossein Beheshti, Mohammad Javad Bahonar, and Mohammad Mofateh. Currently, Mohammad Reza Mahdavi Kani, Ali Akbar Nategh Nouri, Mohammad Emami Kashani, Abbas Ali amidzanjani, are among the key members of the Society of Combatant Clergy of Tehran's central council.

\subsection{Islamic Coalition Party (Hizb-i Mutalifih-yi Islami)}

This party was formed in 1963 by Tehran Market merchants, and is one of the oldest in Iran. Members of this party were some of those who opposed the Shah (King) and took part in the assassination of former Prime Minister Hossein Ali Mansour. After the revolution this group remained united and tried to broaden its influence and power. After the fourth parliamentary election, the party extended its power and influence and recruited new members. It follows the views of The Society of Combatant Clergy of Tehran and this pattern has continued in all elections and the party has never presented its own list. Habibollah Askar Oladi, Asadollah Badamchiyan, Morteza Nabavi, 
Mohammad Kazem Anbarlouei and Taraghi are among the key members of this party. Resalat is their newspaper and Shoma is its weekly paper.

\subsection{Islamic Society of Engineers [ISE](Jemeayi islami yi Mohandesin)}

This conservative group is close to the Islamic Coalition Party, whose decisions they mostly follow. In fact, the party obeys decisions of the Coalition Party and it is questionable whether it is an independent and strong party. Mohammad Reza Bahonar (Note 10) is the Secretary General and its deputy is Ghollam Hossein Amiri. President Mahmoud Ahmadinejad and minister of foreign affairs Manouchehr Mottaki are among its members. After he became president, Ahmadinejad turned against the party and on several occasions denied affiliation of his government and himself to the party and its political wings, despite having years of party experiences. He said: "the ninth government does not owe any party faction and wings except God and the people, and what is important for this government? Just satisfaction of God and the people (Akhavane Kazemi, 2009, p. 158). Also Ahmadinejad's government cut political party subsidies, a remnant of the previous Khatami government. Although people like Askaraoladi, General Secretary of Islamic Coalition Party and the fellowship of Ahmadinejad, criticized the latter's attack on political party culture, this criticism did not shift the Ahmadinejad government from its policy of opposition to parties. The political deputy to Ahmadinejad also suggested that by voting for Ahmadinejad the people were supporting the moves to break up party tyranny.

\subsection{The Population of Defense of the Islamic Values (Jamiate Defa az Arzeshhaye Eslami)}

A political group which started its activities in 1995, its secretary general was Mohammad Mohammadi Reyshahri, the former intelligence minister. On justifying the constitution of this party, he says; "before the fifth election we concluded that we must actively participate in order to fill the present political gap. After this election, statistics showed the lack of a popular political flow. Therefore after the election we concluded that our institution should continue"(Ministry of Culture and Islamic Guidance, 1990a, pp. 440-441). The secretary general of this political institution believes carelessness in Islamic values is another reason for its party constitution. He also believes the Party was established to defend Islamic values (Ministry of Culture and Islamic Guidance, 1990b). We can see the reasons for setting up the party, based on their criticism and objections. These objections can be classified under the following headings (Ministry of Culture and Islamic Guidance, 1990b):

1. Secularism

2. Criticism of the existing two wings due to their absolute stance

3. Corruption, opportunism and reduction in the capacity of tolerating criticism

4. Pragmatism instead of idealism

5. Wrong economic values

6. Bribery and wastefulness in the public sector

7. Revolution transformation and the risk of returning to dependency

\section{Political passivity}

Founders of this party included Mohammad Mohammadi Reyshahri, Sayyed Ali Ghayouri, Sayyed Ali Akbar Aboutorabi, Mohammad Araghi, Ali Razini, Rouhollah Hosseinian, Ahmad Pournejati and Abbass Saleemi Namin. The editorial of Arzeshha weekly paper up to No. 95 (1998) broadly reflected the values and policies of this party, but in late 1998 all party activities were halted. Some of the reasons offered are as follows:

1. Lack of harmony between the members of the central council.

2. Unsuccessful in political activities, for example party candidates did not have any success in the fifth parliamentary and presidential election, and the public hardly paid them any attention.

3. Lack of clear position and failure to present a serious general program for transformation of Iran and the world (Ministry of Culture and Islamic Guidance, 1990b).

\section{The Main Parties from the Left Side}

\subsection{The Association of Combatant Clerics [ACC]( Majma'-i Rouhaniyyun-i Mubariz)}

This party was branched in early 1987, just before the third parliamentary election and the consent of Ayatollah Khomeini from the Society of Combatant Clergy of Tehran (Nozari, 2001). In the third parliamentary election some disagreement arose among members of the Society of Combatant Clergy regarding nomination of candidates and the qualifications and criteria required. Some members were unhappy about endorsing candidates whose behaviour, principles and values, and political background were a cause for concern. These conflicts and disagreements cleared the air over the debate on various ideas within the Society of Combatant Clergy, and eventually some members left 
and founded another clerical party called the Association of Combatant Clerics. This clerical institution consulted with Ayatollah Khomeini and he eventually gave it formal approval (Mousavi Lari, 1996).

This party and others were positioned to gain most seats in the third parliamentary election but following the death of Ayatollah Khomeini, the party and relevant groups fell under the shadow of power. Then in the fourth parliamentary election, most candidates from this party and its affiliated parties were disqualified by the guardian council. This resulted in parties of the left in the Islamic Republic actually being removed from power by a non-democratic method. Understandably, the party lodged complaints over the removal of its candidates, and so propaganda was organized against them which included accusations of acting in an authoritarian way and breaking the law. Therefore from 1991, immediately after the fourth parliamentary election, they stopped their activities for a period of five years. They sought clarification of the ideas of The Association of Combatant Clerics by standing back during this time for the sake of society. One party member said:

After the fourth parliamentary election and its campaign it was not possible to continue our political activities because rival wings accused this clerical organization of trying to gain power in the interests of personalism and group and had a bad influence in the minds of people in society. The qualification of almost 80 of their top party candidates who were nominated for the fourth parliament was disqualified. Rival wings spread propaganda that the most important obstacle to reform and rebuilding the country and providing welfare for the people is the left wing such as the Association of Combatant Clerics, which was an important party in the left wing. In sum, bad conditions before and after the fourth parliamentary election caused the Association of Combatant Clerics to announce the cancellation of their political activities until better times (Ministry of Culture and Islamic Guidance, 1990a, p. 436).

After five years this party resumed its activities in 1995 and announced: "now that the inaccuracy of accusation and propaganda is made clear and it has become obvious the purpose of the party has not been just seeking power and was been doing a duty about Imam and Revolution so, this party announces its existence in political activities" (Ministry of Culture and Islamic Guidance, 1990a).

In the seventh presidential election the party introduced Mohammad Khatami who played an active role in the political campaigns and went on to the presidential election. Two years later they allied with other reformist parties and took most of the seats in the sixth parliament, and although rejecting reform legislation by the Guardian Council, the parliament failed to do important work. During the sixth parliament conflict began to develop within the party began due to the actions of people like Mahdi Karroubi, the General Secretary of this organization who was opposed to the speed of political development suggested by some coalition reformists. He believed coordination with the Supreme Leader was the better approach, and to proceed gradually, and he called his opponents extremist politicians. Although at that time President Mohammad Khatami did not clearly support any group, he did tend more towards the Mujahidin Organization and Participation Front Party (Mosharekat) and his views were more compatible with their ideas. These conflicts continued into the ninth presidential election for which Mahdi Karroubi was nominated but not supported by his party. The Association of Combatant Clerics did not support any of the three reformist candidates and pushed for the removal of Mahdi Karroubi from the party and for the founding of a new party called National Trust Party.

Conflict between the reformist parties resulted in failure in the ninth presidential election and victory to Ahmadinejad by a small majority of votes.

Mohammad Khatami (former president) is the General Secretary of this party and the members who serve on the General Council were close to Ayatollah Khomeini. These people are Mohammad Mousavi Khoieniha, Asadollah Bayat, Rahimian, Imam Jamarani, Rahmani and Ali Akbar Mohtashami.

\subsection{Islamic Revolution Mujahidin Organization (Sazman-i Mujahidin-i Inqilab-i Islami)}

This organization was formed from alliances of seven political groups who believed in the leadership of Ayatollah Khomeini and the armed struggle against the Shah's regime. These groups united after the revolution and were influenced by Ayatollah Khomeini, and after formally announcing their existence in 1979 they were called Islamic Revolution Mujahidin Organization.

The existence of this organization can be divided into two periods, from 1979 to 1982 and from 1982 to 1986 . In 1979, the party asked Ayatollah Khomeini to select his representative or lawyer for supervision of the ideological, theological and practical aspects of the party. Ayatollah Khomeini chose Hojattolislam Rasti Kashani. Given that one of the main economic architects and drivers of this time was a member of the Mujahidin, and given the antipathy of the traditional and conservative party to control of the economy by government, inevitably challenges arose between the representative of Ayatollah Khomeini and other members which caused the party split into three parts: 
1. A group who were not committed to obey the personal ideas of the representative of Ayatollah Khomeini. This group had conservative tendencies in the socio-economic field.

2. A group who did not accept the comments of Ayatollah Khomeini's representative and saw him merely as a spokesman for Ayatollah Khomeini's views, and no more. This group followed the radical economic approach.

3. The third group believed the behaviour of the other two groups was too hostile, and there was no any background for compromise and so resolve the conflicts and continue activities.

The debates inside the organization simply worsened the situation. Finally Ayatollah Khomeini announced "the ones who can work with his representative can stay and others can resign" (Ministry of Culture and Islamic Guidance, 1990b, p. 439). Therefore, in 1982, 38 members resigned but this resignation did not solve the problems and finally, Ayatollah Khomeini's representative made a request for dissolution of the organization and he assented. Some of the members who resigned, due to the closeness of their ideas and the importance of maintaining unity in order to reach their political and ideological goals, kept in touch with each other. Later, after providing a statute request for an activity license, they started to work in 1991. At the seventh presidential election they backed Mohammad Khatami, and most of the leading members entered parliament and then the administration. Behzad Nabavi, who was a key member, became the deputy of the parliament. With so much experience in political activities, this party's members were a great help to Khatami especially in the area of political development.

All the candidates standing for this party were disqualified in the seventh parliamentary election. In ninth presidential election which was won by Mahmud Ahmadinejad, there were no candidates from this party, and they supported a non-party member, Mustafa Moein, who was eligible to stand for election according to the Guardians Council. But he failed in the election because he was not a famous politician, there was low participation due to protests about candidate disqualifications in the seventh parliamentary election, due to public dissatisfaction with focusing too much attention on political issues, a bad economic situation and a major propaganda campaign against reformists.

Mohammad Salamati is secretary general of this party, which has two papers, Asre-ma fortnightly and the weekly Mobin.

\subsection{The Executives of Construction Party (Hezbe Kargozarane Sazandegi)}

This group officially announced its existence just before the fifth parliamentary election but its background goes back to 1989. By the end of the war in 1988 and the presidency of Akbar Hashemi Rafsanjani all the conditions were in place. They took the view that after the Iraq war, old policies designed for war could be ended as Iran faced a new phase.

Their strategy was driven by economic reconstruction and rationalism in foreign policy. Among their key policies was the need to create an environment conducive to attracting international loans to help with reconstruction of infrastructure damaged by the war. To achieve this Iran would have to change its foreign policy and become a more inclusive member of the international community, open to its help and financial support. Western- educated people who influenced Hashemi Rafsanjani had formed this group.

The third parliament, controlled by the left wing, presented an obstacle to this group's views, however, the fourth parliamentary election saw the left losing most seats. In fact, the main reason for the Construction party's victory was a coalition with the Society of Combatant Clergy of Tehran, as their joint aim was removal of the left. During the four years of the fourth parliament, disagreement gradually arose between the Construction party and the Society of Combatant Clergy of Tehran. This worsened and by the fifth parliamentary election, there was no coalition between them. So harsh was the criticism of the Construction Party by the Society of Combatant Clergy of Tehran during the period between the fifth parliamentary and seventh presidential election in 1997, that the former group supported the candidate who opposed the Society of Combatant Clergy of Tehran. During the Khatami presidency most non political positions were given to the Construction party, but in the ninth presidential election this party supported Hashemi Rafsanjani, standing as an independent, rather than the reformist candidate. Their candidate, Hashemi failed however due to the large number of candidates and distribution of the votes and propaganda against him about his corruption.

Ataollah Mohajerani (Note 11), Mohammad Hashemi (Note 12), Ghollam Hossein Karbaschi (Note 13), Mostafa Hashemitaba, Ali and Faezeh Hashemi Rafsanjani (Note 14) are the members of the central council of this party and Ghollam Hossein Karbaschi is the secretary general.

\subsection{Islamic Iran Participation Front (Jebheye Mosharekate Iran-e Eslaami)}

The strongest political party formed after the Islamic Revolution was the Islamic Iran Participation front. This party was established one year after the presidency of Mohammad Khatami by a group of students who followed Ayatollah Khomeini (Note 15). The Participation Front party is composed of three different groups of intellectual: 
1. Middle class revolutionary youths with a left Islamic inclination identified with the perfectionism and practicality. 2. Religious scholars who acquired a humanistic and cooperative approach from political Islam. The main mottos of the Participation Front which underlines their guidelines are "Iran for all Iranians" and spirituality, justice, freedom" which are very similar to the mottos of religious scholars like Dr. Ali Shariati, who had the motto "religion, equality and freedom".

3. Those politicians believing in the growth and success of Iran, attracted to executive power in Hashemi Rafsanjani's government and also believing in liberalism and a free economy.

Founders and members of the Participation Front believe all religious and traditional countries can be accepted among modern countries by relying on the cultural structure of their own countries and just carrying out some reforms to adapt their culture to the modern one. This party was the strongest supporter of President Khatami and had broadly the same policy approach as him. Sayyed Mohammad Khatami's brother, Mohammad Reza Khatami, was the party general secretary. The Participation Front claimed their party's constitution stands up for greater and more direct participation of the people in the political system. Their main method drew on the rule of law and emphasized sustainable development to prevent deep inequalities in society. This party had the largest fraction, 140 out of 290 delegates, in the sixth parliament but in the next parliament, due to candidate disqualifications by the Guardian Council, was only able to secure a few members. Among the key members of the party were Aminzadeh, Mohammadreza Khatami, Hajariyan, Mirdamadi and Tajzadeh. Currently, Mohsen Mirdamadi is the general secretary.

\subsection{National Trust Party (Hezbe Etemade Melli)}

During the ninth presidential election in 2005, there was conflict between Mahdi Karroubi (Note 16) and his friends in the Association of Combatant Clerics (ACC) and after his failure in the election, he resigned from the ACC and founded a new party called National Trust. Their announced aim was to secure institutionalization of party activities in Iran (Karroubi, 2005). After founding the National Trust Party, Karroubi objected to reforms in the sixth parliament and took a new attitude in the eighth parliamentary elections; he announced there would not be any coalition with other reformist parties (Bahari, 2007). Although, Mahdi Karroubi regarded himself as a reformist, he criticized Mohammad Khatami for giving too much freedom to the extremists to ruin reform. He believed his failure in the 2005 election was due to fraud. Undaunted, Karroubi continued his efforts to gain control over the executive power and in the tenth presidential election (2009) made himself a candidate, attracting support from a wide variety of scholars. This election had the greatest participation since the Islamic Revolution ( 84 percent) but reformists said the election was rigged and didn't accept the result. Mahdi Karroubi, General Secretary of the National Trust Party, was one of the candidates not accepting the election result, stating he believed fraud on a massive scale took place in the election. Although he has been an active manger in the Iranian political system in recent years, however, at present he is known as the most popular opposition leader among Iranian people. This party wants to have good relations with the USA. The party's central council members are: Mahdi Karroubi, Montajabniya, Khabaz, Reza Hojati, Reza Ansary and Abolfazl Shakouri.

\section{Similarities and Differences of Parties in the Islamic Republic of Iran}

After explaining the party formation process in the country, introducing their views and plans, this study will discuss the most important similarities and differences between parties from a political, economical and cultural point of view.

\subsection{Comparing the Political Views of the Parties in Iran}

\subsubsection{Selection of the Supreme leader}

Parties have differing views about the role of people in choosing the Supreme Leader. The right parties (Right Wing) don't believe it is the people's role to choose the Supreme Leader. Instead, they believe it is the duty of the Assembly of Experts (Note 17) to "discover" the supreme leader, not to choose him. Meanwhile, the left parties (Left Wing) believe the existence of the Supreme Leader is under the control of the people.

\subsubsection{The Authorities of the Supreme Leader}

The Left believe the authorities are limited by the Constitution, while the Right consider his authorities are beyond the Constitution. The Right says the Supreme Leader is only responsible to God and does not have any responsibilities to the people, which is wholly against the principles of the Left parties.

\subsubsection{The Holiness of the Supreme Leader}

While the Right think the Supreme Leader is holy and should not be criticized by anyone, the left are strongly opposed to this view and say he can make political mistakes just like others politicians. 


\subsubsection{The Ruling Right in the Islamic Republic of Iran}

The right in Iran give the ruling right to God, however, the left believe this right is given to people unlike the right party. They say the most important factor in decision-making is the popular vote.

\subsubsection{Islamic Government and Democracy}

Some on the right claim there is no democracy in Islam as such a principal is fundamentally against Islamic thoughts. In effect in Islam the views of the people are not important, and Islamic Law is the only basis for governing society and this can be deduced by the religious leaders for the benefit of society. People are there mainly just as supporters and followers who only have to obey the religious leader; the pioneer of this school of thought is Ayatollah Mohammad Taghi Mesbahhe Yazdi. On the contrary, the left considers the democratic vote of the people as the only means of governing society and Islam is the religion of freedom and democracy, otherwise the government is not an Islamic one.

\subsubsection{Freedom}

Freedom is viewed by the left as the natural right of people while the right believes it is a privilege government gives to the people. So parties of the right, such as the Society of Combatant Clergy of Tehran, Islamic coalition party and Islamic Society of Engineers, take the second view of freedom.

\subsubsection{Political Participation}

The left sees political participation by the people as a party or political institution but parties of the right, except for The Population of Defense of the Islamic Values, see citizen participation only in activities such as taking part in demonstrations, attending Friday prayers etc.

\subsubsection{Export the revolution}

Parties of the right believe the Islamic Revolution should be exported to other countries, however, the left emphasize strongly the need to focus on domestic problems and set a good example of the Islamic Revolution which other countries may practice in their own country.

\subsubsection{Foreign Policies}

The right has an anti-foreigner position and its main concern is maintaining the traditional culture which is their only shelter. Parties of the right fear any changes in traditional belief may weaken their political power. In fact, the foreign policy of the two groups can be divided into two distinct directions; with the left taking a liberal approach while the right parties take a radical stance.

\subsection{Comparing the Economical Views of Political Parties in Iran}

\subsubsection{Privatization}

Shortly after the revolution parties of the left believed the state should be dominant in the economy and control the market, and they were against privatization. Meanwhile the right supported free trade policies with the least amount of government control over the economy, but today both parties have the same views. At the outset of the Islamic Revolution, whenever the Left Party under Mir Hossein Mousavi's leadership had control over government, they adopted a policy of strict control over the market with a state economy and they did not favour the private sector. This trend changed fundamentally when Hashemi Rafsanjani became president in the 1990s. Here is a brief outline of what happened:

Output growth, privatization, the creation of free-trade zones, utilizing foreign resources, encouraging Iranian investors living aboard, removal of government subsidies, free imports, increasing social welfare and public services, economic security and consumption growth. Despite voices of disagreement from expert advisers from the former government who were on the left, the new government took the view that it was essential to implement these new economic policies to help the Iranian economy recover and grow after the shock of the war period. Later, Khatami continued the economic policy direction introduced by Hashemi, though he modified its speed and placed more emphasis on cultural and political issues aggressively opposed by the left.

\subsubsection{Using of Foreign Resources}

At the outset of the Islamic Revolution, the Left Parties were against using foreign loans and imposed strict laws on foreign currency pricing and other economic controls, but the right was in favour of using foreign resources to develop the country. At the present time both Parties have the same views.

\subsubsection{Social Justice}

All the Right wing parties believe social justice should be a priority in the economic sphere. This approach is also shared by the Left leaning parties. Alone as a dissenting voice is the Executives of the Construction Party who believe as long as Iran has not developed valuable assets should not be redistributed. 


\subsection{The Comparison Of Cultural Views Among Political Parties In Iran}

\subsubsection{Supervision over Cultural Activities}

There are two different views on supervision of cultural products. While the Left believes in supervision over cultural products after publication, parties of the Right takes a more interventionist and censorious approach, believing in supervision before publication.

\subsubsection{Cultural Exchange}

Across the political spectrum there is some disagreement about cultural exchange. While the Left stresses the appreciation of value and sees positive points in other cultures, the Right opposes this position of the Left, believing their own culture is richer than others.

\subsubsection{Cultural Policy}

While the Left Parties believe in a pluralistic and open cultural policy, the Right emphasizes cultural control. The Left opposes government interference in cultural activities, as they believe the government should just supervise and offer guidance over the cultural activities, but the Right strongly defends government control over cultural activities.

Where do the parties stand on matters of tradition and modernity? The Left is not too sensitive about the traditions, believing in revising traditions and making them efficient and relevant for today. This view is supportive of modernism in culture, but the Right Parties believe in tradition and in maintaining the existing status and are against modernism.

\subsubsection{Cultural Invasion}

Debate about the cultural invasion has been raised by the Right since 1989. These parties really believe the superpowers intend to penetrate culturally the Islamic community and replace it with old colonialism which was to plunder the properties of countries. They take the view that the only way to stop the cultural invasion is to prevent young Iranians from accessing western cultural output, so they have strongly opposed new media devices like video, internet and satellite and prevented people accessing T.V channels. Meanwhile, the Left believes if there is a cultural invasion the state cannot hinder access to new information. They believe it is better to allow free flow of information, and pay to secure society and promote Iranian culture and community. In this way, the left believes, there will be less influence on society by satellite, networks and Western cultural products.

\section{Conclusion}

This study has considered the formation of political parties in Iran along with a brief history and a discussion of their values and goals. Then a comparison was made of the respective party views and their similarities and differences were discussed. The key political parties, divided into the Left and the Right Parties, are: The Association of Combatant Clerics, the Executives of Construction Party, Islamic Revolution Mojahedin Organization, Islamic Iran Participation front party, National Trust Party are among those on the Left, while Islamic coalition party, Society of Combatant Clergy of Tehran, Islamic Society of Engineers and the Population of Defense of the Islamic Values are among the Right wing parties.

These parties engage in political, economic and cultural issues, for example, the Right Parties tends to emphasize traditional culture over modernism, while on the contrary the Left Parties are not very sensitive to this issue and believe in revision, revitalization and making tradition more effective and support use of modernism in culture. In foreign policy, the Right Party is radical and the Left Party is liberal. In economic issues all parties believe in the free market economy and the expansion of trade.

\section{References}

Akhavane Kazemi, B. (2009). The Causes of Inefficiency of Iran's Political Parties. Tehran: Markaze Enghelabe Eslami.

Almond, G. A. \& Powell, G. B. (1966). Comparative politics: a developmental approach. Boston: Little.

Bahar, m. (1942). History of political parties in Iran Tehran: Chape Rangin.

Bahari, M. (2007). Karroubi'S Interview with Newsweek, from http://www.fardanews.com/fa/pages/?cid=47713

Biezen, V. I. (2004). Political parties as public utilities. Sage, 10(6 ), 701-722.

Duverger, M. (1964). Political parties, their organization and activity in the modern state (2d ed.). London: Science Editions.

Karroubi, M. (2005). Karroubi's letter to Supreme Leader, from http://www.bbc.co.uk/persian/iran/story/2005/06/050619_karoubi-objection.shtml 
Lapalombara, J., \& Weiner, M. (1966). Political Party and Political Development. New Jersey: Princeton University Press.

Lipset, s. M. s., Rokkan (1967). Party system and voter alignment. New York: Free Press.

Michels, R. (2001). Political parties a sociological study of the oligarchical tendencies of modern democracy

Ministry of Culture and Islamic Guidance (1990a). Ideas Confrontation (Vol. 2). Tehran: Ministry of Culture and Islamic Guidance.

Ministry of Culture and Islamic Guidance (1990b). Ideas Confrontation (Vol. 1). Tehran: Ministry of Culture and Islamic Guidance.

Mortajy, H. (2000). Confrontation ideas, Published Articles (Vol. 1). Tehran: Ministry of Culture and Islamic Guidance.

Mousavi Lari, A. (1996). Interview with Mousavi Lari. Salam,

Naghibzadeh, A. (1999). Hezbe Siasi va amalkarde an (Political Parties and their functions. Tehran: Dadgostar.

National Democratic Institute for International Affairs. (2001). A Guide to Political Party Development

Nozari, e. (2001). History of political party in Iran. Shiraz: Navid.

\section{Notes}

Note 1. First Iranian President after Islamic Revolution

Note 2. The first Head of the Judiciary after Islamic Revolution

Note 3. Head of Former Judiciary

Note 4. Former Iranian president and

Note 5. Current supreme leader of the Islamic Republic of Iran

Note 6. Former Prime Minister of the Islamic Republic of Iran

Note 7. Former Prime Minister of the Islamic Republic of Iran

Note 8. Ayatollah Kashani was one of the prominent religious leaders during the oil nationalization in Iran (1953)

Note 9. Speaker of Fifth Parliament

Note 10. Vice Speaker of Sixth and Seventh Parliament

Note 11.Former Minister of Culture and Islamic Guidance

Note 12.Brother of the former Iranian president Hashemi Rafsanjani and a member of the party central committee of Construction of Executers of Iran

Note 13. Former mayor of Tehran

Note 14. Son and daughter of former Iranian president Hashemi Rafsanjani

Note 15. follower students of ayatollah Khomeini occupied American Embassy in 1980 and were hostage a number of American Embassy Staff for 444 days

Note 16. Speaker of sixth parliament

Note 17. Assembly of Experts is including clergy that based on Article 107 of the constitution has duty of selection supreme leader after Ayatollah Khomeini. Each period is the eight years and its members selected by election and by the direct vote, and the number of representatives is 86 